\title{
Pterodon pubescens seed extract induces the cell cycle arrest of leukemic cells by deregulating cyclin D1 and E2 mRNA levels
}

\author{
MONICA FARAH PEREIRA, TATIANA DE ALMEIDA SIMÃO, SÉRGIO RANTO DALMAU, \\ RODOLPHO MATTOS ALBANO, MARSEN GARCIA PINTO COELHO and KATIA COSTA DE CARVALHO SABINO
}

\author{
Departamento de Bioquímica, Instituto de Biologia Roberto Alcantara Gomes, \\ Universidade do Estado do Rio de Janeiro, CEP-20550-170 Rio de Janeiro, RJ, Brazil
}

Received September 28, 2009; Accepted January 26, 2010

DOI: 10.3892/ol_00000094

\begin{abstract}
Plant-derived compounds are important sources of effective anti-cancer agents. Pterodon pubescens is a native Brazilian plant popularly known for its anti-inflammatory and anti-arthritic effects. The ethanolic extract of its seeds (EEPp) is a viscous, brown and fragrant oil containing geranylgeraniol, farnesol, naphthalene, dimethyldodecatrienol and vouacapan diterpene derivatives, in addition to other compounds. This study investigated the in vitro anti-leukemic properties of EEPp using the resistant human leukemia cell line K562. The EEPp anti-proliferative effect was demonstrated by the inhibition of DNA synthesis and cell growth, and the induction of cell cycle arrest in the $\mathrm{G}_{1}$ phase. Furthermore, cyclin E2 mRNA levels were down-regulated, while those of cyclin D1 were up-regulated. An EEPp anti-leukemic effect may have also triggered apoptosis, as it increased the number of shrunken cells and phosphatidylserine cell membrane exposure. These observations suggest that EEPp deregulates cyclin D1 and E2 expression, inducing cell cycle arrest and apoptosis of leukemic cells.
\end{abstract}

\section{Introduction}

Cancer is the second leading cause of human mortality worldwide, and conventional therapies are known for their serious side effects. Therefore, many efforts have been made to determine novel alternative approaches for the prevention or treatment of cancer. Advances in cancer research have shown that alterations in the expression or function of genes that control the cell cycle and apoptosis enhance tumor survival

Correspondence to: Dr Katia Costa de Carvalho Sabino, Departamento de Bioquímica, Instituto de Biologia, Centro Biomédico, Universidade do Estado do Rio de Janeiro, Av. Professor Manoel de Abreu 444, 4º Andar, CEP-20550-170 Rio de Janeiro, RJ, Brazil

E-mail: kasabino2000@yahoo.com.br

Key words: apoptosis, cell cycle, cyclins, K562 cells, leukemia, Pterodon pubescens through the disruption of the balance between these processes. Plants have been used as a source of anti-cancer agents since the 1950s, when the alkaloids vinblastine and vincristine were isolated from Catharanthus roseus G. Don. Chemotherapeutic agents in clinical use such as paclitaxel and flavopiridol (1) are also derived from plants.

Pterodon pubescens Benth. (Leguminosae-Papilionoidea) is popularly known as 'Sucupira branca', and its seeds are used in folk medicine to treat rheumatic and inflammatory diseases. Scientific data have confirmed the anti-arthritic effects of the hydroalcoholic extract of Pterodon pubescens seeds in type II collagen-induced arthritis in mice without subacute toxic effects (2-4). Although anti-inflammatory action has been noted for the seed ethanolic extract (EEPp) (5), anti-proliferative effects on leukemic cells have yet to be demonstrated. The present study showed that EEPp deregulates cyclin D1 and E2 mRNA expression by inducing cell cycle arrest in the $\mathrm{G}_{1}$ phase and apoptosis in the chronic myelogenous leukemia K562.

\section{Materials and methods}

Extract preparation. The seeds of Pterodon pubescens Benth. were collected by Luciana Pontes Coelho in Goiás, Brazil, and identified by Haroldo Cavalcante de Lima at the Jardim Botânico do Estado do Rio de Janeiro, Brazil, where a voucher was deposited (RB 350279). The powdered seeds were submitted to $100 \%$ ethanol $(15 \mathrm{~g} / 100 \mathrm{ml})$ for 15 days. Following ethanol evaporation, the viscous oil (EEPp) was obtained, yielding 50\% (w/w). EEPp was dissolved in ethanol and then diluted with a supplemented medium consisting of RPMI-1640 with $10 \%$ fetal bovine serum (Cultilab, Brazil), penicillin $(70 \mathrm{mg} / \mathrm{l})$ and streptomycin $(100 \mathrm{mg} / \mathrm{l})$ to a final ethanol concentration of $0.01 \%$. Control cultures received only $0.01 \%$ ethanol in the supplemented medium.

Cell growth. The human chronic myelogenous leukemia cell line K562 (CCL-243), purchased from the American Type Culture Collection, was always cultured $\left(2.5 \times 10^{5}\right.$ cells $\left./ \mathrm{ml}\right)$ in the supplemented medium. For cell growth, the cell line was treated with 10,30 or $50 \mu \mathrm{g} / \mathrm{ml}$ EEPp for $72 \mathrm{~h}$ at $37^{\circ} \mathrm{C}$ and $5 \%$ $\mathrm{CO}_{2}$. Viable cells (by trypan blue dye exclusion) were counted at a 12 -h interval. 
Cell proliferation assay. The cells were cultured in 96-well plates $(200 \mu \mathrm{l})$ with different EEPp concentrations and $0.25 \mu \mathrm{Ci} /$ well $\left[{ }^{3} \mathrm{H}\right]$-methyl-thymidine (Amersham Biosciences, Brazil) for $24 \mathrm{~h}$ at $37^{\circ} \mathrm{C}$ in $5 \% \mathrm{CO}_{2}$. Subsequently, the cells were harvested on filter papers and processed for the determination of ${ }^{3} \mathrm{H}-\mathrm{Tdr}$ radioactivity using liquid scintillation.

Cell cycle analysis. Cells were cultured with $30 \mu \mathrm{g} / \mathrm{ml}$ EEPp for $36 \mathrm{~h}$ at $37^{\circ} \mathrm{C}$ in $5 \% \mathrm{CO}_{2}$. After centrifugation $(400 \mathrm{x} \mathrm{g})$, $1 \times 10^{6}$ viable cells were treated with $0.3 \%$ Triton $\mathrm{X}-100$ containing $50 \mu \mathrm{g} / \mathrm{ml}$ propidium iodide (PI) in $43 \mathrm{mM}$ citrate buffer solution ( $\mathrm{pH} \mathrm{8.2)} \mathrm{for} 15 \mathrm{~min}$ in the dark, and then with $500 \mu \mathrm{l}$ of $100 \mu \mathrm{g} / \mathrm{ml}$ ribonuclease A (Sigma Chemical Co., USA) for $15 \mathrm{~min}$. PI fluorescence $(585 \pm 15 \mathrm{~nm})$ was measured $(100,000$ events) using a FACSCalibur cytometer (BecktonDickinson, USA), and data were analyzed using the WinMdi 2.8 software.

Analysis of apoptosis using flow cytometry. Cells were treated with $50 \mu \mathrm{g} / \mathrm{ml}$ EEPp for $36 \mathrm{~h}$ at $37^{\circ} \mathrm{C}$ in $5 \% \mathrm{CO}_{2}$. Cell death was evaluated by the loss of membrane integrity (high PI fluorescence at $485 \mathrm{~nm}$ ) after treatment with PI solution (final concentration $2 \mu \mathrm{g} / \mathrm{ml}$ ). Apoptosis was determined by cell shrinkage (size reduction) and evaluated by the forward-scatter (FSC) parameter. Phosphatidylserine exposure was then determined using the Annexin V-FITC/PI double staining kit (BD Pharmingen, USA). Briefly, cells $\left(1 \times 10^{5}\right)$ were washed with PBS, suspended in binding buffer (10 mM HEPES $\mathrm{pH} 7.4,140 \mathrm{mM} \mathrm{NaCl}$ and $2.5 \mathrm{mM} \mathrm{CaCl})_{2}$ and treated with Annexin V $(5 \mu \mathrm{l})$ and $50 \mu \mathrm{g} / \mathrm{ml}$ PI solution $(10 \mu \mathrm{l})$ for $15 \mathrm{~min}$ at room temperature. Annexin binding was determined by FITC fluorescence $(535 \pm 15 \mathrm{~nm})$. Cells (105/assay) were obtained using Cell Quest software and analyzed using WinMdi 2.8 software.

Analysis of mRNA expression using RT-PCR. Total RNA was extracted using TRIzol (Invitrogen). The reverse transcription reaction was performed by adding MMLV reverse transcriptase (Invitrogen), RNA and random primers to the reaction mixture. PCR was performed in a Perkin Elmer GeneAmp PCR System 9600. cDNA was added to a 25- $\mu$ 1 PCR mixture containing dNTP, the specific primers and Platinum Taq DNA polymerase (Invitrogen). Each cycle consisted of $30 \mathrm{sec}$ at $94^{\circ} \mathrm{C}, 30$ sec at annealing temperature, and $1 \mathrm{~min}$ at $72^{\circ} \mathrm{C}$. The PCR products were resolved on a $2 \%$ agarose-ethidium bromide gel and quantified by Lab Image software (Germany). The primers used were: GAPDH (housekeeping gene), forward 5'-TGTGAACGGATTTGGCCGTA-3' and reverse 5'-TCGCTCCTGGAAGATGGTGA-3' $\quad\left(58^{\circ} \mathrm{C}, \quad 30\right.$ cycles, 200 bp); cyclin D1, forward 5'-CTGGCCATGAACTACCT GGA-3' and reverse 5'-GTCACACTTGATCACTCTGG-3' $\left(59^{\circ} \mathrm{C}, 30\right.$ cycles, $\left.482 \mathrm{bp}\right)$ and cyclin E2, forward 5'-ATCCAGG CCAAGAAGAGGAAA-3' and reverse 5'-GCACAAGGCAG CAGCAGTC-3' $\left(63^{\circ} \mathrm{C}, 32\right.$ cycles, $\left.612 \mathrm{bp}\right)$.

Statistical analysis. Significant differences between the two groups were assessed using Student's t-test, with a level of significance set at $\mathrm{p}<0.05$.
A

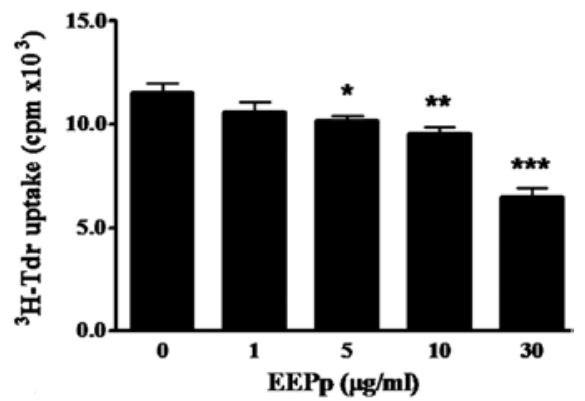

B

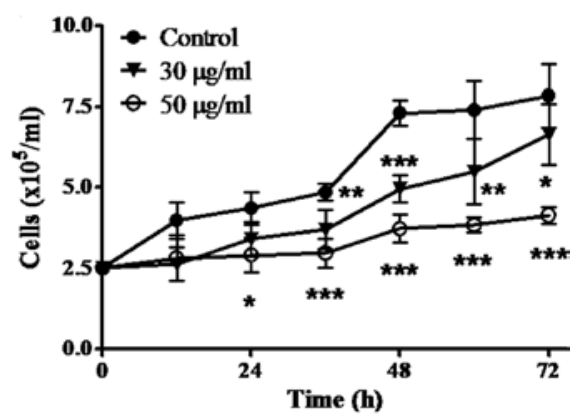

Figure 1. The effects of EEPp on K562 leukemic cell proliferation. Cells $\left(2.5 \times 10^{5} / \mathrm{ml}\right)$ were incubated in the absence (control) or presence of EEPp. (A) Cell proliferation by ${ }^{3} \mathrm{H}$-thymidine incorporation $(0.2 \mu \mathrm{Ci} /$ well/24 h) after $24 \mathrm{~h}$. (B) Cell growth curve. Viable cells were regularly counted using trypan blue dye exclusion. Results represent the mean \pm SD of three independent experiments in triplicate. ${ }^{*} \mathrm{p}<0.05,{ }^{* *} \mathrm{p}<0.01$ and ${ }^{* * *} \mathrm{p}<0.001$ relative to the control (Student's t-test).
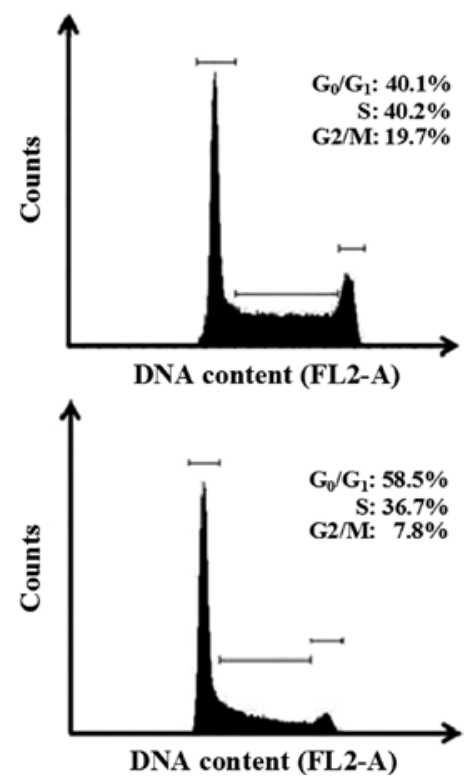

Figure 2. Flow cytometric analysis of the effect of EEPp on the K562 cell cycle. Histograms show the fluorescence of PI-stained nuclei (DNA content, FL2-A) of cultures in the absence (upper) or presence of EEPp $50 \mu \mathrm{g}$ / $\mathrm{ml}$ (lower) for $36 \mathrm{~h}$. Hypodiploid nuclei and debris were discarded from the analysis. Cells were processed as described in Materials and methods. The percentage represents the results from three independent experiments.

\section{Results}

This study reports on the effect of EEPp on the proliferation of K562 leukemic cells using different methods. The 
$\mathbf{A}$

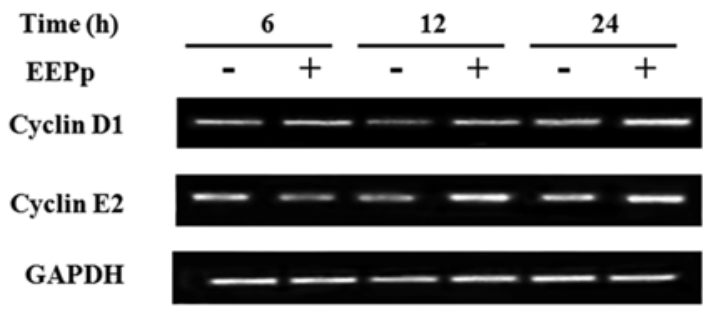

B

C
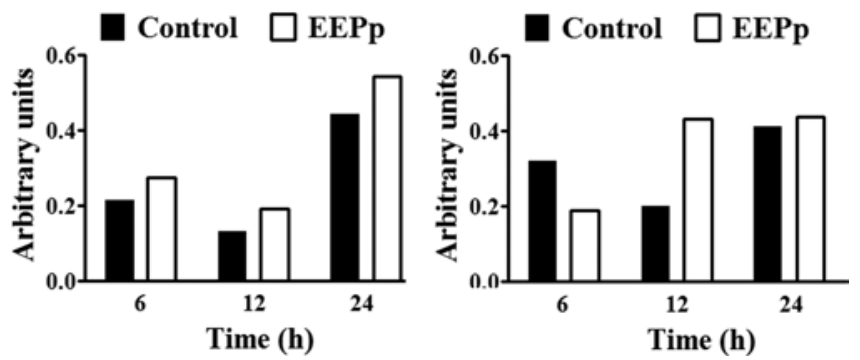

Figure 3. RT-PCR analysis of cyclin D1 and E2 mRNA expression after the treatment of K562 cells with EEPp (30 $\mu \mathrm{g} / \mathrm{ml})$. (A) Agarose gel electrophoresis. (B) Quantification of cyclin D1 and (C) E2 expression. Densitometric analysis was performed using Gel Pro software with GAPDH mRNA expression as the loading control (representative result from three independent experiments).

A

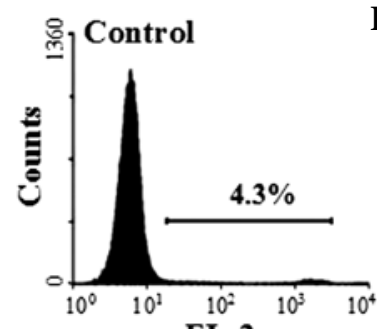

FL-2

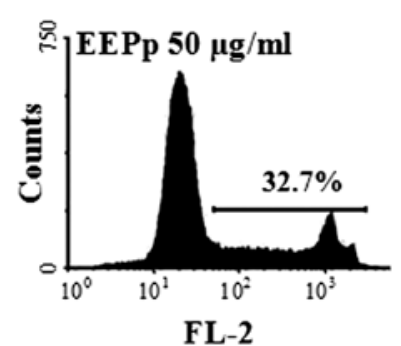

B

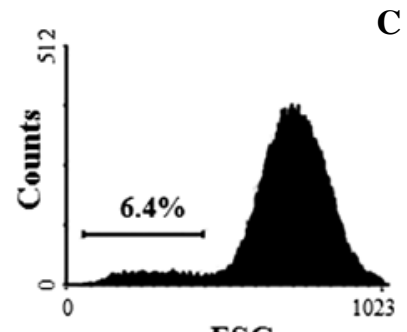

FSC

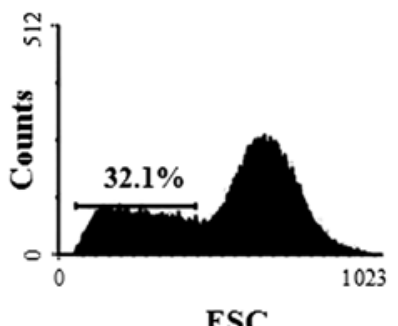

C

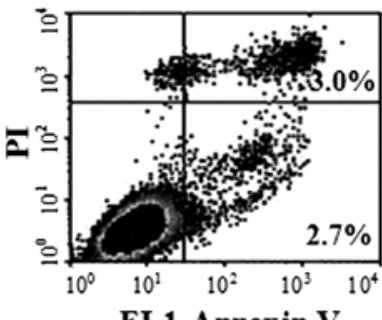

FL1-Annexin V

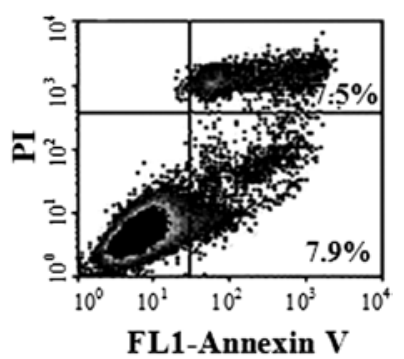

Figure 4. Flow cytometric analysis of the effect of EEPp on K562 leukemic cell apoptosis. (A) Histogram of PI fluorescence (FL-2), (B) histogram of cell size (FSC) and (C) Annexin V-FITC/PI double staining cytogram. Cells $\left(2.5 \times 10^{5} / \mathrm{ml}\right)$ were cultured for $36 \mathrm{~h}$ without EEPp (control, upper panels) or with $50 \mu \mathrm{g} / \mathrm{ml}$ EEPp (lower panels) and processed as described in Materials and methods. Cell death was evaluated by the loss of membrane integrity (high PI fluorescence at $485 \mathrm{~nm}$ ), and apoptosis was evaluated by analysis of shrunken (reduced size) or Annexin V-positive cells. The lower left quadrant indicates viable cells (Annexin $\mathrm{V}^{-} / \mathrm{PI}^{-}$), the upper left quadrant indicates necrotic cells (Annexin $\mathrm{V}^{-} / \mathrm{PI}^{+}$), the lower right quadrant indicates apoptotic cells $\left(\right.$Annexin $\mathrm{V}^{+} / \mathrm{PI}^{-}$) and the upper right quadrant indicates the late apoptotic cells (Annexin $\mathrm{V}^{+} / \mathrm{PI}^{+}$). Results are representative of three independent experiments.

incorporation of ${ }^{3} \mathrm{H}-\mathrm{Tdr}$ to DNA was significantly inhibited after a 24-h incubation (Fig. 1A). This effect began at $5 \mu \mathrm{g} / \mathrm{ml}$ $\operatorname{EEPp}(\mathrm{p}<0.05)$, reaching $44 \%$ inhibition at $30 \mu \mathrm{g} / \mathrm{ml}(\mathrm{p}<0.001)$. EEPp also induced a concentration- and time-dependent cell growth inhibition (Fig. 1B). When cultures were treated with EEPp at $30 \mu \mathrm{g} / \mathrm{ml}$, cell growth was only slightly inhibited, while intense and continuous inhibition levels (70-80\%) were observed at $50 \mu \mathrm{g} / \mathrm{ml}$.

The anti-proliferative effects of EEPp with regard to other cell cycle phases were also studied. The histograms in Fig. 2 show a nuclear PI fluorescence distribution that is proportional to the DNA content (FL2-A). EEPp at $50 \mu \mathrm{g} / \mathrm{ml}$ effectively arrested K562 cell cycle progression from the $G_{1}$ to the $\mathrm{S}$ phase (Fig. 2, lower panel). Apoptotic bodies, nuclear fragments or nuclear doublets were eliminated from the analysis. In this representative experiment, $50 \mu \mathrm{g} / \mathrm{ml} \mathrm{EEPp} \mathrm{induced}$ a $45 \%$ increase in cells at the $G_{1}$ phase, while cell numbers at the $\mathrm{S}$ and $\mathrm{G}_{2} / \mathrm{M}$ phases reciprocally decreased by 16 and $60 \%$, respectively. These effects were confirmed by analyzing the mean of three independent experiments (data not shown). The relative number of cells at $\mathrm{G}_{0} / \mathrm{G}_{1}, \mathrm{~S}$ and $\mathrm{G}_{2} / \mathrm{M}$ phases in the control cultures was $40.1 \pm 1.2,40.2 \pm 1.1$ and $18.7 \pm 0.9 \%$, 
respectively. In the presence of $50 \mu \mathrm{g} / \mathrm{ml}$ EEPp these numbers changed to $60.2 \pm 2.5 \%$ (50\% increase, $\mathrm{p}<0.01$ ), $31.8 \pm 2.6 \%$ $(21 \%$ reduction, $\mathrm{p}=0.054)$ and $7.9 \pm 0.1 \%$ (58\% reduction, $\mathrm{p}<0.01$ ), respectively.

Analysis of cyclin mRNA expression using RT-PCR is shown in Fig. 3A. Control cultures exhibited a reduction in cyclin D1 mRNA levels at $12 \mathrm{~h}$ and an increase at $24 \mathrm{~h}$ (Fig. 3B), similar to cyclin E2 mRNA levels (Fig. 3C). EEPp at $30 \mu \mathrm{g} / \mathrm{ml}$ induced a higher cyclin D1 mRNA expression at all of the times analyzed (Fig. 3B). This concentration caused a reduction in cyclin E2 expression at $6 \mathrm{~h}$ and an increase at $12 \mathrm{~h}$ (Fig. 3C).

Apart from inhibiting cell proliferation and inducing cell cycle arrest at the $\mathrm{G}_{1}$ phase, EEPp at $50 \mu \mathrm{g} / \mathrm{ml}$ also induced K562 cell death (Fig. 4A). An increase in the relative number of shrunken cells from 6.4 to $32 \%$ (Fig. 4B) indicated that EEPp induces leukemic cells into apoptosis, which was confirmed by the increase in Annexin V-positive cells from 5.7 to $15.4 \%$ (Fig. 4 C).

\section{Discussion}

Many plant products have been found to possess chemotherapeutic activities both in vitro and in vivo (6). This study noted the anti-proliferative activity of EEPp on chronic myelogenous leukemia-derived K562 cells. EEPp inhibited DNA synthesis, cell growth and arrested the cell cycle at the $\mathrm{G}_{1}$ phase, similar to other plant extracts with anti-tumoral activity (6). This effect was not due to ethanol, since ethanol treatment of the control cultures did not alter the responses (data not shown). Vieira and collaborators reported the anti-proliferative activity of a crude ethanolic extract of Pterodon pubescens seeds against the human melanoma cell line SK MEL 37, but data were not presented (7).

Cyclins D1 and E2 activate specific cyclin-dependent kinases, inducing the cell cycle progression from the $G_{1}$ to $S$ phase. In contrast to conventional drugs which inhibit tumor cell line proliferation by reducing cyclin D1 mRNA levels, EEPp treatment increased it. Similar results have been reported for other cell lines (8). The reduction in cyclin E2 mRNA expression in tumor cells by EEEp treatment $(6 \mathrm{~h})$ has also been described for several anti-cancer agents (9).

Traditional chemotherapeutic agents and potential anticancer drugs (6) deregulate cell cycle components, triggering apoptosis in tumor cells. EEPp induced K562 cells into apoptosis despite their mutated TP53 tumor suppressor gene and resistance to several anti-cancer drugs (10), suggesting that this effect occurs through a p53-independent mechanism.

EEPp is a viscous, brown and fragrant oil, containing geranylgeraniol, farnesol, naphthalene, dimethyldodecatrienol and vouacapan diterpene derivatives (5,7). A vouacapan diterpene, isolated from a Pterodon pubescens extract, was shown to reduce proliferation and induce apoptosis of melanoma cells (7). The compounds geranylgeraniol and farnesol were shown to induce tumor cell anti-proliferative effects (11) and apoptosis $(12,13)$. Thus, different substances present in EEPp may be involved in its anti-leukemic effects.
This study showed that the ethanolic extract of Pterodon pubescens seeds induced the cell cycle arrest and apoptosis of a resistant leukemic cell line and that the deregulation of D1 and E2 cyclin mRNA expression may be related to these anti-proliferative effects. The fractionation of this extract as well as experiments to clarify other mechanisms involved in the anti-leukemic effects of EEPp are currently in progress.

\section{Acknowledgements}

We thank the LIA-BPPN Laboratory personnel for their technical assistance. This study was supported by FAPERJ (E-26/171.330/2006).

\section{References}

1. Cragg GM and Newman DJ: Plants as a source of anti-cancer agents. J Ethnopharmacol 100: 72-79, 2005.

2. Sabino KCC, Castro FA, Oliveira JCR, Dalmau SRA and Coelho MGP: Successful therapy of collagen-induced arthritis in mice with a hydroalcoholic extract of seeds of Pterodon pubescens. Phytother Res 13: 613-615, 1999.

3. Coelho MGP, Marques PR, Gayer CRM, Vaz LCA Nogueira Neto JF and Sabino KCC: Subacute toxicity evaluation of a hydroalcoholic extract of Pterodon pubescens seeds in mice with collagen-induced arthritis. J Ethnopharmacol 77: 159-164, 2001.

4. Coelho MGP, Sabino KCC and Dalmau SR: Immunomodulatory effects of sucupira (Pterodon pubescens) seed infusion on collagen-induced arthritis. Clin Exp Rheumatol 22: 213-218, 2004.

5. Silva MC, Gayer CR, Lopes CS, et al: Acute and topic antiedematogenic fractions isolated from the seeds of Pterodon pubescens. J Pharm Pharmacol 56: 135-141, 2004.

6. Reddy L, Odhav B and Bhoola KD: Natural products for cancer prevention: a global perspective. Pharmacol Ther 99: 1-13, 2003.

7. Vieira CR, Marques MF, Soares PR, et al: Antiproliferative activity of Pterodon pubescens Benth. seed oil and its active principle on human melanoma cells. Phytomedicine 15: 528-532, 2008.

8. Okabe H, Lee SH, Phuchareon J, Albertson DG, McCormick F and Tetsu O: A critical role for FBXW8 and MAPK in cyclin D1 degradation and cancer cell proliferation. PLoS ONE 1: e128, 2006.

9. Diaz-Carballo D, Malak S, Freistühler M, Elmaagacli A, Bardenheuer W and Reusch HP: Nemorosone blocks proliferation and induces apoptosis in leukemia cells. Int $\mathbf{J}$ Clin Pharmacol Ther 46: 428-439, 2008.

10. Pytel D, Wysocki T and Majsterek I: Comparative study of DNA damage, cell cycle and apoptosis in human K562 and CCRF-CEM leukemia cells: role of BCR/ABL I therapeutic resistance. Comp Biochem Physiol 144: 85-92, 2006.

11. Miquel K, Pradines A, Tercé F, Selmi S and Favre G: Competitive inhibition of choline phosphotransferase by geranylgeraniol and farnesol inhibits phosphatidylcholine synthesis and induces apoptosis in human lung adenocarcinoma A549 cells. J Biol Chem 40: 26179-26186, 1998

12. Masuda Y, Nakaya M, Aiuchi T, Hashimoto S, Nakajo S and Nakaya K: The mechanism of geranylgeraniol-induced apoptosis involves activation, by a caspase-3-like protease, of a c-Jun $\mathrm{N}$-terminal kinase signaling cascade and differs from mechanisms of apoptosis induced by conventional chemotherapeutic drugs. Leuk Res 24: 937-950, 2000.

13. Rioja A, Pizzey AR, Marson CM and Thomas NS: Preferential induction of apoptosis of leukaemic cells by farnesol. FEBS Lett 467: 291-295, 2000. 